\section{$196 / 4,2^{573}$ \\ LA-5386-MS}
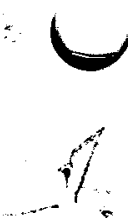

$+$

\section{INFORMAL REPORT}

$$
45538
$$

\section{Seismic Program}

of the Los Alamos Scientific Laboratory

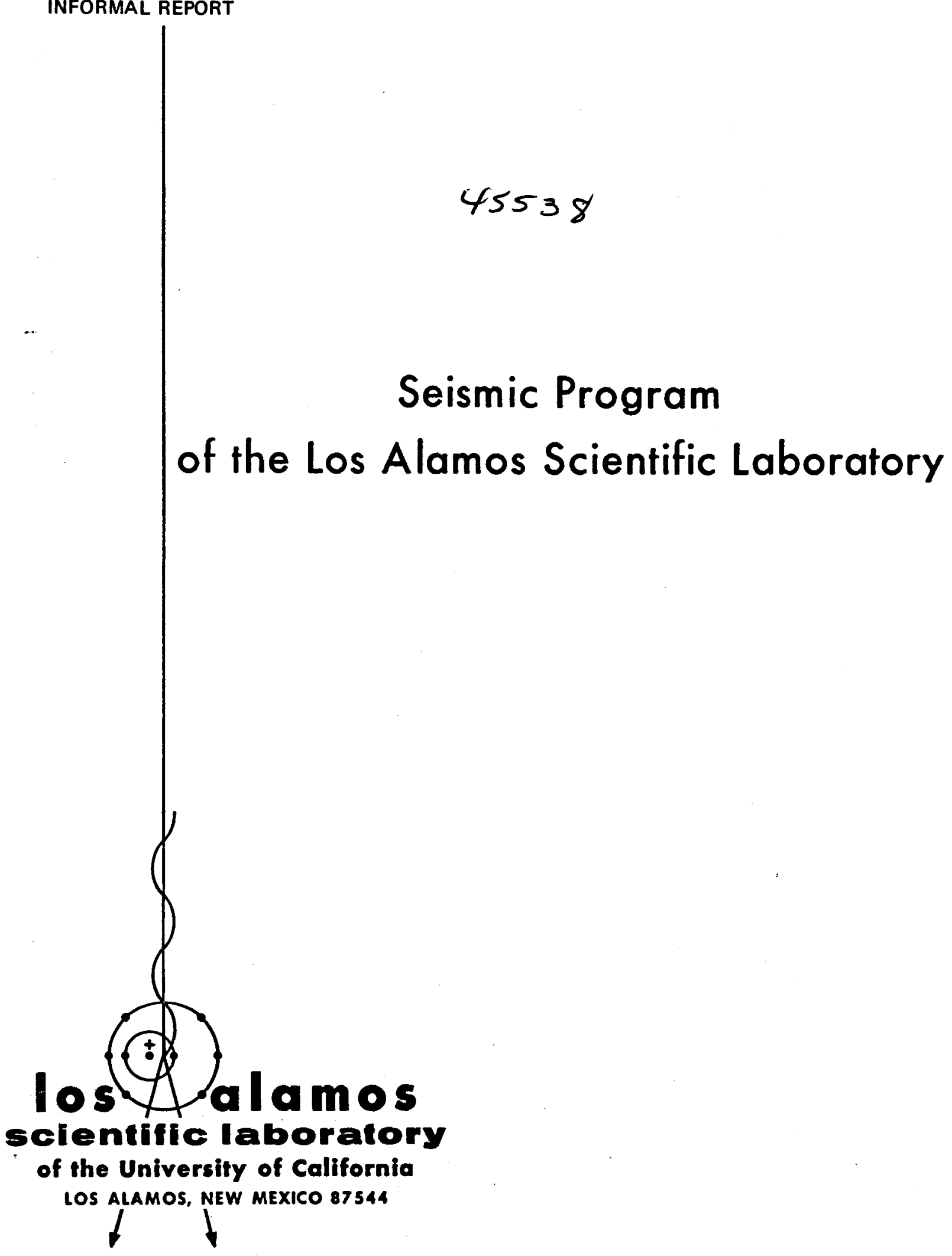




\section{DISCLAIMER}

This report was prepared as an account of work sponsored by an agency of the United States Government. Neither the United States Government nor any agency Thereof, nor any of their employees, makes any warranty, express or implied, or assumes any legal liability or responsibility for the accuracy, completeness, or usefulness of any information, apparatus, product, or process disclosed, or represents that its use would not infringe privately owned rights. Reference herein to any specific commercial product, process, or service by trade name, trademark, manufacturer, or otherwise does not necessarily constitute or imply its endorsement, recommendation, or favoring by the United States Government or any agency thereof. The views and opinions of authors expressed herein do not necessarily state or reflect those of the United States Government or any agency thereof. 


\section{DISCLAIMER}

Portions of this document may be illegible in electronic image products. Images are produced from the best available original document. 
This report was prepared as an account of work sponsored by the United States Government. Neither the United States nor the United States Atomic Energy Commission, nor any of their employees, nor any of their contractors, subcontractors, or their employees, makes any warranty, express or implied, or assumes any legal liability or responsibility for the accuracy, completeness or usefulness of any information, apparatus, product or process disclosed, or represents that its use would not infringe privately owned rights.

In the interest of prompt distribution, this LAMS report was not edited by the Technical Information staff.

Printed in the United States of America. Available from National Technical Information Service

U. S. Department of Commerce

5285 Port Royal Road

Springfield, Virginia 22151

Price: Printed Copy $\$ 4.00$; Microfiche $\$ 0.95$ 
LA-5386-MS

Informal Report

UC-11

ISSUED: September 1973

\title{
Seismic Program
}

\section{of the Los Alamos Scientific Laboratory}

\author{
Compiled by
}

W. D. Purtymun

H. S. Jordan

NOTICE

This report was prepared os an account of work

sponsored by the United States Government. Neither the United States nor the United States Atomic Energy Commission, nor any of their employees, nor any of their contractors, subcontractors, or their employees,

makes any warranty, express or implied, or assumes any

lecal lisbility or responsibility for the accuracy, com.

Jogal Habilty or respotion

preteness or usefulness of any information, apparatus,

product or process disclosed, or represents
would not infringe privately owned rights. 


\title{
SEISMIC PROGRAM OF THE
}

LOS ALAMOS SCIENTIFIC LABORATORY

\author{
Compiled by \\ W. D. Purtymun \\ and
}

H. S. Jordan

\begin{abstract}
There are four areas of interest in seismic programs at Los Alamos: (1) Environmental studies, (2) Seismic studies in connection with the Geothermal Program, (3) Underground explosive test event studies, and (4) Strong motion studies. The purpose of this paper is to outline areas of study and their objectives and to propose a policy statement.
\end{abstract}

\section{INTRODUCTION}

The community and laboratories in LOS

Alamos County are located on the Pajarito Plateau in North Central New Mexico. The plateau is structurally a part of the Rio Grande depression--a camplex series of faulted troughs or basins that extend from Southern Colorado through Central New Mexico to Mexico (Fig. 1). The formation of the depres sion began 18 to 21 million years ago. The geologic evidence (truncation of alluvial fans by faulting in Southern Colorado and seismic activity Taos to Socorro) indicates that adjustments in the depression are still taking place. In the past several years there has been an increase in activity in the depression from Taos to Albuquerque.

The depression in the Los Alamos area is from 30 to 40 miles in width. The bas ement rocks are down-faulted to a depth of about $5000 \mathrm{ft}$ below sea level forming a nortik-south trending trough beneath the central part of the plateau. The trough is filled with about $12,000 \mathrm{ft}$ of volcanics and sediments. The development of the depression by faulting was accompanied by sedimentation and intermittent eruptions of basalts. These basalts form the Cerros del Rio volcanic field to the east of Los Alamos. The basalts underly the communities of White Rock and Pajarito Acres and are interbedded with sediments beneath the plateau. It is thought that the ages of these basalts may range from about 18 million years to less than 40,000 years.

The formation of the Jemez Volcanic Field began millions of years ago. It reached a culmination of activity about one million years ago with the explosive ejection of ashfall and ashflow tuffs resulting in the Valles Caldera, a circular-shaped depression some 20 miles in diameter. The ashflows and ashfalls of tuff ejected from the caldera form the surface of the Pajarito Plateau. Subsequent 


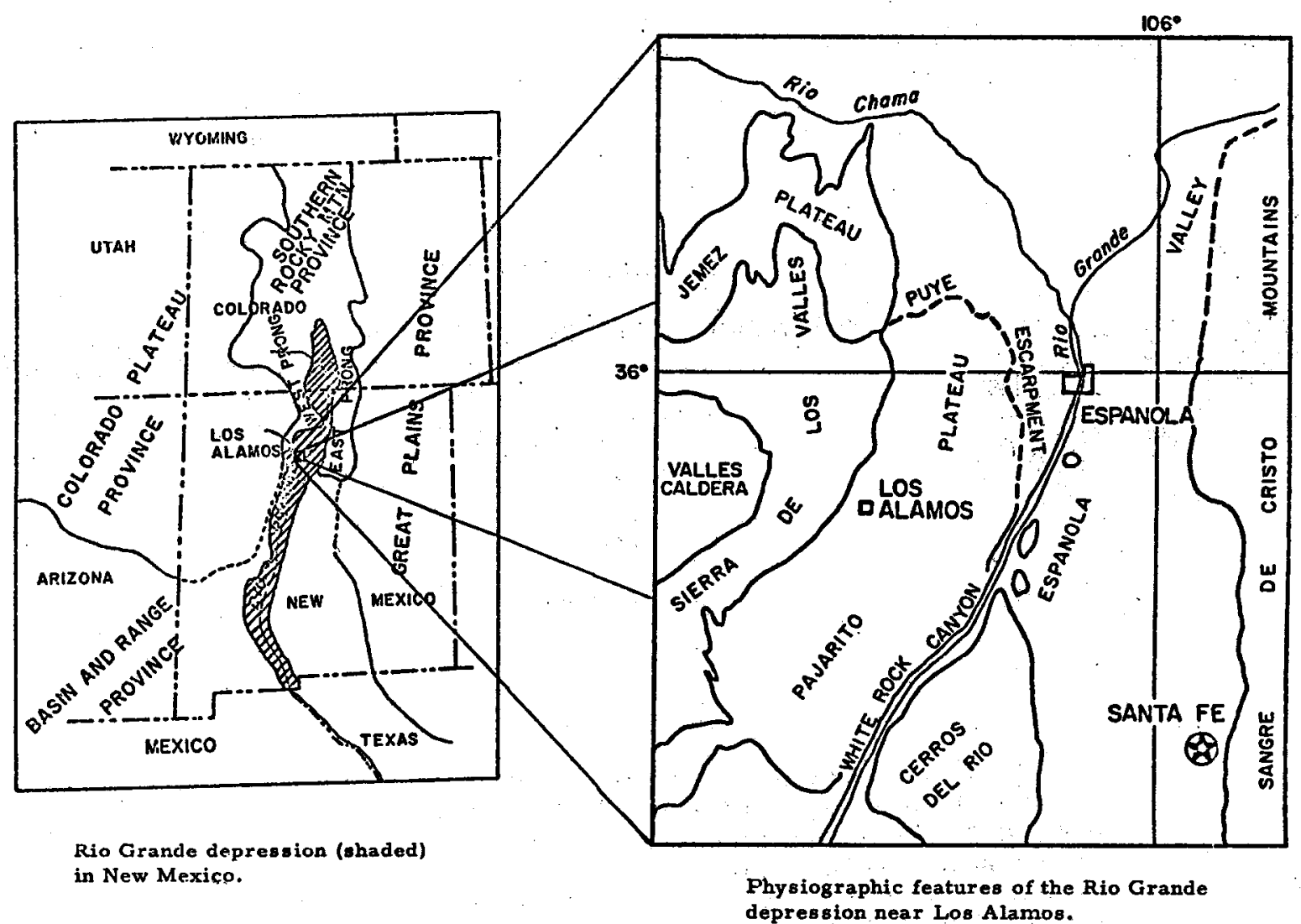

Fig. 1. Rio Grande depression in New Mexico and physiographic features near Los Alamos.

volcanic activity continued with the extrusion of intra-caldera domes and ejection of pumice that occurred 40,000 to 100,000 years ago. Present. hot springs activity and wells producing steam in the caldera result from residual heat of magma at depth.

Clearly, the geologic regime that can produce seismic activity is present in the area. The seismic activity could be related to failure of rocks by stress set up along fault or fault zones in the Rio Grande depression or the expansion or movement of magmas along volcanic vents or chambers in Cerros del Rio or Valles Caldera volcanic fields. Other elements that could cause increased seismic activity are the works of man. An increase in activity could result from the filling of the dam at Cochiti when completed in 1974 or 1975. The loading by the impounded water has caused rock failure and increased seismic activity at some dam sites in the world, e. g. , Hoover Dam. An increase in the activity could possibly be caused by exploration and development of geothermal energy in the area. The induced pressure in drill holes to create dry geothermal reservoirs (a IASL study) or the withdrawal of steam and water from wet geothermal reservoir (commercial company) could cause an increase in seismic activity. Explosive test events, depending upon the size of the event, produceaftershocks and signals similar to naturally occurring seismic activity.

There are three seismograph stations in New Mexico (Albuquerque, Socorro, and Las Cruces), two stations in southern Colorado (Trinidad and Mesa Verde), and one in West Texas (E1 Paso). A seismic station was located in the southern part of Los Alamos in January 1972 . The station is operated by $\mathrm{J}-9$, LASL.

The purpose of this paper is to outline the areas of study and their objectives and to propose a policy statement. This paper was prepared at 
the request of Richard F. Taschek, Associate Director for Research.

The four areas of interest in seismic studies are: (1) Environmental studies, (2) Seismic studies in connection with the Geothermal Program, (3) Underground explosive test event studies, and (4) Strong motion documentation.

\section{ENVIRONMENTAL AND SAFETY ANALYSIS STUDIES}

Studies of the local seismicity should be made to determine seismic regimes and seismic risk. A study should be completed prior to completion of the dam at Cochiti and prior to any geothermal experiments by LASL. The long term aspect of the study would indicate that at least one permanent, rather sophisticated, station should be established immediately, and outlying stations established before starting hydraulic fracturing activities in the Geothermal Program. The actual location of all stations will be in areas where cultural noise is at a minimum. An investigation of the local area with portable instrumentation will be required to determine station locations. The outlying stations are to contain single vertical components while the main station will be a three-component station (one vertical and two horizontal seismometers). The data from the outlying stations should be relayed to a central control station by RF telemetry or leased telephone lines. The magnification of the seismometers should be high, 100,000 or greater, in order to monitor microearthquakes with magnitudes of less than 2. The outlying stations and the main station should provide continuous records 24 hours a day, 7 days a week. The purpose of the proposed seismic net is to provide the following:

1. Background data on seismic activity prior to any geothermal experiments by the Laboratory in the Jemez area.

2. Documentation of seismic activity dur ing a geothermal experiment and for any follow-on operations after experiment.
3. Background data on seismic activity in the Los Alamos area prior to the completion of Cochiti Dam.

4. Documentation of seismic activity that may be induced by filling of the Cochiti reservoir.

5. Basic seismic data for engineering, environmental and safety studies of future Laboratory experimental or construction activity.

6. Basic seismic data for engineering, environmental and safety studies of existing Laboratory facilities.

7. Basic seismic data for the State of New Mexico.

The data from the environmental studies will provide (1) number of shocks, (2) magnitude, and (3) location. The precise location of the earthquake origin from the seismic net should allow identification of geologic features (faulting or volcanism) that are involved. The location of the active area relative to facilities in Los Alamos and the GTE Site is necessary to evaluate the seismic risk. An analysis of time-history of seismic events is necessary to determine if activity is continuous or of a sporadic type. The lack of instrumentation data for this locality makes it difficult to assign a value for the prevailing seismic risk. The documentation of microevents will be an input into this determination by the relationship associating frequency and magnitude of seismic events. Documentation of the background seismicity of the region is required to detect changes due to the filling of the reservoir behind Cochiti Dam or experimentation at the GTE Site. This organized body of information will be needed by the Laboratory for the development of Environmental Impact Statements and Safety Analyses Reports; for the evaluation of the seismic risk associated with the GTE experiment; for the evaluation of future site location for buildings and laboratories; and for discrimination studies of explosive test events and natural seismic activity. 
III.

GEOTHERMAL STUDIES

The Geothermal Energy Program (Group

Q-22) is based on the development of a dry hot res ervoir in competent rock by hydraulic fracturing to create the energy reservoir. The hydraulic fracturing will provide a source of tensile stress which when fracturing takes place will result in seismic signals. These seismic signals should have a different character than signals produced by volcanism or tectonic activity. After the reservoir is created and the circulation loop is established through the reservoir, additional fracturing of the reservoir rock will take place due to the contraction of the rock. This fracturing will also result in seismic activity that could be picked up by sensitive seismic equipment. It will be necessary to establish this seismic array close in at. the GTE Site on the surface as well as to adapt some instrumentation for emplacement down bore holes adjacent to the site. This experimental study is independent of the environmental study and hence special equipment and instrumentation will be needed. Data from the environmental net, however, would be used to supplement the study. The seismic effort for the GTE Site would yield data on the following: (1) seismic background in the vicinity of the proposed GTE Site prior to any major experiment, (2) magnitude of aeismic activity during initial breakdown of rock during hydraulic fracturing, (3) orientation and approximate radii of fracture, (4) "natural" microearthquakes that might be stimulated by overpressurization, (5) life of reservoir by continued monitoring by seismic signals the growth of the fracture due to extraction of heat,

- and (6) the safe spectrum of injection pressure and total volume injected in which a geothermal system will be functional without the release of dangerous seismic energy. Along with the engineering aspect applicable for the development of geothermal energy, the study would yield seismic data to increase the understanding of the nature, characteristics, propagation, recording, and of interpretation of the different type of acoustic signal that will contribute directly to the national program of earthquake invęstigations.

IV. UNDERGROUND EXPLOSIVE TEST EVENTS The vibratory effects caused by the energy released during underground explosive test events are presently being monitored by a net of five stations operated by J-9. The stations located at various sites in the technical areas on the Pajarito Plateau are operated at short periods of time prior to, during, and after an anticipated release of energy in the tuff. The instruments are operated at a magnification of about 15,000 to 150,000 . One station where cultural noise is at a minimum is operated 24-hours a day at a magnification of about 100,000; however, the cultural noise level even for this station is such that only the night and weekerid recording periods produce useful data. During working hours, cultural noise masks the lower levels of local natural seismic activity.

The five stations are operated at low magnification to evaluate near-surface shear wave velocities from artificial energy released at various distances. The studies are made to relate energy release to possible damage and to develop within the Laboratory the needed specialized knowledge related to the detection of underground test events.

\section{STRONG MOTION STUDIES \\ Design engineers are concerned about earth} motion of sufficient strength to cause structural damage to buildings: Such motion is only recorded by "strong motion" instruments with static magnification in the range of 1 to 20. The recorder is not continuous but is triggered when strong shocks occur. The instrument is not designed for location of epicenters or investigations of the earth's crust or geologic features but to study strong motion that can be related to structural design criteria. The strong motion seismogram makes it possible to set up spectrum analyses for moderately heavy shocks 
and find the distribution of energy over the frequency range. The seismographs that would be used in the environmental studies are not suited for this determination. Aside from the spectrum analyses for engineering application for design of the earthquakeresistant structures, the records are important in evaluating the energy release from an earthquake and examining the relation between intensity and acceleration. The data are also needed to determine the required investigative procedure for continuing operation of certain facilities, i. e., reactors and plutonium-handling facilities, in the event Los Alamos experiences an earthquake of an intensity equal to that used for the design basis for the facility. It is also obvious that seismic criteria will probably be an increasingly important consideration for critical installations, and the Laboratory, therefore, should move at once to start accumulating basic data.

\section{STATUS OF STUDIES}

As of June 1973, the regional environmental studies are based on operation of one seismograph operated by J-9 (a part of underground explosive test events study) which is operated at a magnification of about 100,000 . The operation of this station is a stop-gap to fill in until a regional net, telemetry and central recording station can be established. The equipment necessary for the net, telemetry and central station have been order ed and delivery will be completed by the end of FY-73. Field surveys as to acceptable sites for seismograph stations are being made (see Memo J-9-OU72-486, attached as an Appendix). A-strong motion seismograph has also been ordered and received. Installation will be made in the next few weeks after the instrument has been calibrated.

Development and initial field testing of microseismic instrumentation suitable for geother mal energy studies has been initiated. In particular, a project has been proposed for the geothermal studies as a research with a Schedule 189 submitted (prepared May 10, 1972, resubmitted May 10, 1973): J-9 is monitoring with a small surface array the seismic signals generated by a small scale hydraulic fracturing experiment being carried out at Granite Test 1 by the Geothermal Group (March 1973).

The underground explosive test event studies began in January 1972 and are in progress. These studies are being conducted by J-9.

\section{STATUS OF STUDIES BY CONSULTANTS}

Dr. David B. Slemmons, Mackay School of

Mines, University of Nevada, began a study in March 1972 which has resulted in the draft of a report; "Analysis of Fault Activity and Seismicity Near the Proposed Geothermal Test Site in the Jemez Mountains." The report, after review, will probably be published as a LAMS (Los Alamos Manuscript Report).

Dr. Allan R. Sanford, of New Mexico Institute of Mining and Technology (NMMMT), began a study on the "Seismicity of the Los Alamos Region Based on Seismological Data, "in March 1972. The study based on short term instrumental data (five months' records from J-9) was complete in July and a final report was transmitted in September 1972.

A third study undertaken by Dr. A. J. Budding of NMIMT, began in April 1972 and was completed January 1; 1973. This study conducted in the immediate Los Alamos area relates fault characteristics to theoretical data on magnitude of shocks produced from rupture along faults or fault zones. It is essentially the same type of study that was completed by Dr. Slemmons for the Geothermal Site west of Los Alamos.

David Leeds of Dames and Moore, Consulting Engineers, has completed a study of earthquake design parameters for the Los Alamos area. The results of the study are included in the report, "Geology, Foundation, Hydrology, andSeismic Investigations for the Plutonium Processing Facilities." 
Group $\mathrm{H}-8$ is now in process of consolidating three reports (Sanford, Budding, and Leeds) into a single copy for publication as a LAMS report. Consolidation of the three reports will make the material readily available for the Laboratory as well as the technical community. In the interim, the three reports are available for inspection at $\mathrm{H}-8$ Group Office.

\section{LABORATORY POLICY}

The problem confronting the Laboratory is the necessity to engage in the projects examined above with limited funds. The immediate concern, then, is to formulate a Laboratory policy that outlines and fixes responsibilities in a reasonable program that could be pursued with available resources. The following is a proposed policy statement.

It shall be the policy of the LASL to establish a program in seismology that will provide for:

a. An instrumentation array that will provide continuous recording of microseismic events in the Los Alamos area.

b. Documentation of strong motion seismic events.

c. Data accumulation, analysis and reporting that will ultimately be instrumental in defining the seismic risk at Los Alamos.

d. Special instrumentation and intensified monitoring activities for LASL experiments with possible seismic considerations, i. e., geothermal and underground explosive test events.

e. Development of knowledge and understanding of the seismic signals produced by underground explosive test events.

\section{A. General Statement}

The present level of funding prevents the formation of a Seismic Group within the Laboratory. Group J-9 is engaged in special seismic research. Thus, they have a staff which can provide guidance in the four programs. The following assignments are established to aid various groups in accomplishing the program with available resources.
B. Environmental and Safety Analyses Studies

Seismic instrumentation will be the responsibility of Group J-9. The instrumented array for documentation of microseismic events will be developed, specified, installed, and maintained by J-9. Group J-9 will be responsible for accumulating, analyzing, and reporting the data generated by the instrumented microseismic array. Data currently being collected from the single station are exchanged with similar data collected by NMIMT. Retention of a consultant from NMIMT is being finalized by J-9 to provide consultation for IASL programs.

Groups H-8 and Eng-7 will be responsible for assessing all pertinent information on seismic activity in the Los Alamos area and maintaining for the Laboratory a current position on seismic considerations involved in Environmental Statements, Safety Analysis Reports, and siting criteria for new facilities.

C. Geothermal Studies

Project Manager of the GTE program is responsible for the instrumentation and experimental procedure for monitoring onsite the seismic activity associated with GTE experiments. Development of special instrumentation requirements will be coordinated with Group J-9.

Group J-9 will be responsible for establishing any necessary additional stations to enable the microseismic monitoring net to provide data on the seismic activity, if any, generated by the GTEprogram.

\section{Underground Explosive Test Events}

Group J-9 will maintain an instrumented array for documentation of seismic activity associated with underground explosive test events, in accordance with weapon development programmatic requir ements. Accumulation, analysis, and reporting of data from this program will be the responsibility of Group J-9. 
E. Strong Motion Stadies

Group J-9 will be responsible for the speci-

fication, installation, and maintenance of a strong motion station. Analysis and reporting of data obtained from this station will be coordinated with Groups H-8 and Eng-7. 


\section{APPENDIX}

The following memo was prepared by K. H. Olsen, J-9, on seismic studies and is found in their files as Memo J9-OU-72-486, dated 12/22/72.

This memo is intended to provide general information on some aspects of the program of seismic studies being undertaken at LASL by Group J-9. Here we want specifically to outline contemplated instrument locations so that negotiations may be started with the AEC, Forest Service, and perhaps private parties for land access permits and for the necessary approvals for telephone line and radio frequency telemetry links.

\section{objectives}

1. The prime objective of the planned network of seismic sensors is to gather spatial and temporal data on microselsmic (magnitude less than 2) activity in the Los Alamos/Jemez Mountain area of northern New Mexico. In order to map the locations, depths and source motions of these small natural earthquakes, a network of at least four stations recording continuously over a period of several years is required. In order to be effective, the network should encompass the areas of prime interest and the stations should be located on suitable bedrock formations in regions where there is a minimum of locally generated background ground vibration noise due to cultural aetivity (e.g. traffic vibrations). The requirement for station remoteness has to be tempered by the requirement for not too difficult access for maintenance and repair and the fact that some locations (e.g. mountaintops) may turn out to be susceptible to high background noise generated by winds. Station separations between 3 and 15 miles are needed.

The data gathered on the network are to be used in earthquake risk analyses for LASL facilities in general and for certain unique LASL facilities elther already bullt or being contemplated (e.g. Meson facility, Plutonium facility). The iminence of drilling and fracturing experiments for the LASL geothermal program and related questions of possible triggering of small selsmic events also requires the accumulation of the background microseismic data.

2. The network is planned so as to support special localized high frequency selsmic measurements to be made during the geothermal project's pumping and hydrofracturing experiments in the vicinity of La Cueva. 
3. The network of short perlod instruments discussed here would also provide part of the data from distant events to be used in J Division research on earthquake/underground explosion discrimination and on basic sclentific research in other aspects of selsmology.

\section{Preliminary Site Surveys}

Before setting up the network of permanent selsmometer stations, each proposed location area has to be checked for sultability from the standpolnts of proper geology, acceptable selsmlc background nolse levels, radio transmission tests for the telemetry links and reasonable security of our equipment from vandalism or other man-caused interference. The selomic equipment to be used for these surveys is shown In Figure 2 and consists of a selsmometer, portable tape recorder, two watertight boxes containing the time code reference unit and the amplifiers. The system operates for about 4 days from five 12 volt auto storage batteries. The magnetic tape holds four days of continuous data. The seismic background checkout of a particular location involves digging a shallow hole in the sol1 so as to place the selsmometer on bedrock and recording for several days. The equipment is left unattended during the recording period. The recorder and time code generator can be placed several hundred feet away from the selsmometer location if desired. The time code generator and tape recorder can operate from 110 volt power outlets if they are convenlent thus eliminating the need for the five batteries. The radio propagation tests to be made by $E$ Division at each site also Involve portable equipment and could probably be completed in a days time. Depending on the topography and geology at each Individual site area, several tests within a mile or 60 of the nominal locations 1isted in Table 1 and Figure 1 may be necessary before a final site is located which is compatible with both the seismic and radio propagation requirements. The equipment shown in Figure 2 is now ready for deployment and we wish to begin the selsmic surveys as soon as land access approvals can be obtalned and weather conditions permit.

\section{Permanent Stations}

The equipment to be used for the remote sites for the permanent network consists of a seismometer, the amplifier box, and batteries as shown in Figure 2 along with a low power ( 0.1 to 1 watt radiated power) radio. transmitter and a directional FM antenna mounted on a telephone pole or other sultable mast. The radio units will be contained in weatherproof boxes similar to the amplifler bozes. Since the radio frequencies to be used are line-of-sight VHF (164-172 MHZ band), several of the stations w111 require relay link stations on Intermediate mountains or other high points in order to bring the signals to the recording station at SM 43 (Administration building) in Los Alamos. The relay station would consist 
of a low power transceiver palr and antennas plus special battery power units which would enable the radios to operate continuously for up to perhaps one year before the batteries had to be changed.

Both selsmometer/transmitter stations and radio relay stations could operate from commercial power if these facilities happen to be located conveniently near a site with good selsmic characteristics. Also it is desirable to transmit the data by leased telephone line rather than radio if these are convenlently nearby and can be leased at reasonable cost. The construction cost involved in running special telephone 1ines to most of the remote areas is likely to be prohibitive.

In the permanent configuration, the selsmometer and amplifier would either be buried under the topsoll or be placed in a small (about 3 foot diameter) lockable vault which would have an internal concrete pad resting on bedrock. Fifty to one hundred feet of wire would connect the amplifier output to the radio transmitter or telephone line nearby. The central recording station at SM 43 is already recording phone line telemetered data from several selsmometer units located in laboratory technical areas. The additional recording equipment suffictent for recording signals from the off-lab net being discussed here will be installed between January and April 1973, so we would want to start setting up the permanent stations one by one as soon this coming spring as the seismic surveys and land use arrangements can be completed.

\section{Details of Tentative Sites}

Table 1 and Figure 1 give some detalls of the specific areas chosen on the basis of preliminary geologic, topographic, and access considerations and limits of possible microearthquake coverage. In most cases the numbered locations in Figure 1 are intended to Indicate areas about a mile in diameter whlch are to be tested rather than locations that are precisely known at this time. Locations marked 9 and 10 are even 1 ess precisely known at this time and further definition will have to awalt the opportunity to make trips to these areas. In general we have tried to place tentative remote sites on National Forest land when possible, belleving that the land access problems would be easier on Government lands.

It is not intended to locate permanent stations at every site shown in Figure 1 but to indicate where we wish to make the preliminary surveys. Depending on the tests and the outcome of discussions with those controlling the land, we will likely have to revise this list with both additions and deletions as the program progresses. 
TABLE A-I

Tentative Sites for

Selemic and/or Radio Telemetry Relays

1. Upper Pajarito Canyon - Seismometer s1te. There appear to be sultable bedrock outcrops west of State Road 4 on Los Alamos County land. We wish to be west of the Pajarito fault zone which parallels the highway in this reglon. Power and telephone lines now run alongside Route 4 and we would want to consider the possibilities of running power and telephone cables along or near the ground from a site In this region to the existing lines.

2. On Pajarito mountain reasonably near the Camp May road - Selsmometer site. This is not separated very far from Site 1 and we would probably not want to make permanent installations at both County controlled land.

3. Guaje Canyon area - Selsmometer site. County land. The desire here is to locate a station in the northern part of the county and would be especially useful if the problems of getting Into Chicoma Mountain (Site 10) make a station there impractical. Guaje Mountain is being considered as a possible radio relay station. Caballo Mountain also may have to be considered as an alternative.

4. Near TA-33 probably on LASL controlled land - Selsmometer station. The mesa top near TA-33 is geologically Inferior and we wauld want to consider placing the selsmometer over the canyon rim on a basalt outcrop. It is Iikely that this station could easily be tied in with existing LASL controlled telephone circults.

5. East of the Rio Grande on the Caja del Rio Grant - Selsmometer station. This would probably require a short radio link to $\mathrm{TA}-33$ and thence into the lab phone circults. The geology of this region makes it appear a much better candidate than $\mathrm{TA}-33$ and only one of the two would probably be used. It is our understanding that this land is administered by the Forest Service rather than one of the Pueblos.

6. St. Peter's dome - Seismometer site. Forest land. Geology is good and it would appear fairly easy to transmit radio data from the vicinity of the fire lookout direct to the SM 43 recording station.

7. Near Triple H Ranch/Conchas Campground in Valle Grande - Seismometer site. The desired geological formation (basalt) is south of State Road 4. Forest land is probably preferable from the standpoint of access but an acceptable selsmometer location near here may be in the narrow Jemez Creek Canyon and present difficulties for radio data 
transmission. A region near the intersection of Route 4 with the del Norte Canyon road may be better from the radio standpoint but may also involve access to Baca land.

8. Near Horseshoe Springs. This selsmometer station is to be lacated near the site of the proposed GT-2 Geothermal Test well on Forest land. For special experiments we may later consider a subarray of seismometers within a couple of miles of this station feeding aignals back to the central location. We understand that it is reasonable to expect to use existing commercial power and lease telephone lines from this area since the existing lines run close by.

9. Near Encino Peak - Selsmometer s1te. Forest land. The proper geology exists near Forest Route $\# 100$ in this area but not much 1s known yet about the specific problems of relaying radio data out of the area.

10. Near Chlcoma Peak - Selmometer site. Forest land. Good geology. A station in this general area is needed to complete a "ring" of selsmic coverage of the Valles Caldera. Chicoma Peak may also have to be considered for a radio relay station but the problems of ease of access and servicing have not yet been seriously addressed.

11. Redondo Peak area -

12. Rabbit Mountain -

13. Pajarito Mountaln or other nearby high point on the Valles Caldera rim. These three sites are under consideration mainly for radio relay stations. Redondo and Rabbit Mt. are on Baca land; the higher points near Pajarito Hountain are near the borderline between Baca land and LOs Alamos County and so may involve either.

14. La Cueva - Mixture of Forest land and private property. Unfavorable geology and the likelihood of high cultural background nolse do not favor this area for a permanent selomometer location. However, the proximity of the geothermal test well area (\$8) and the likely avallability of power and telephone lines would indicate that a careful survey of this area should be made to assess its potential. 


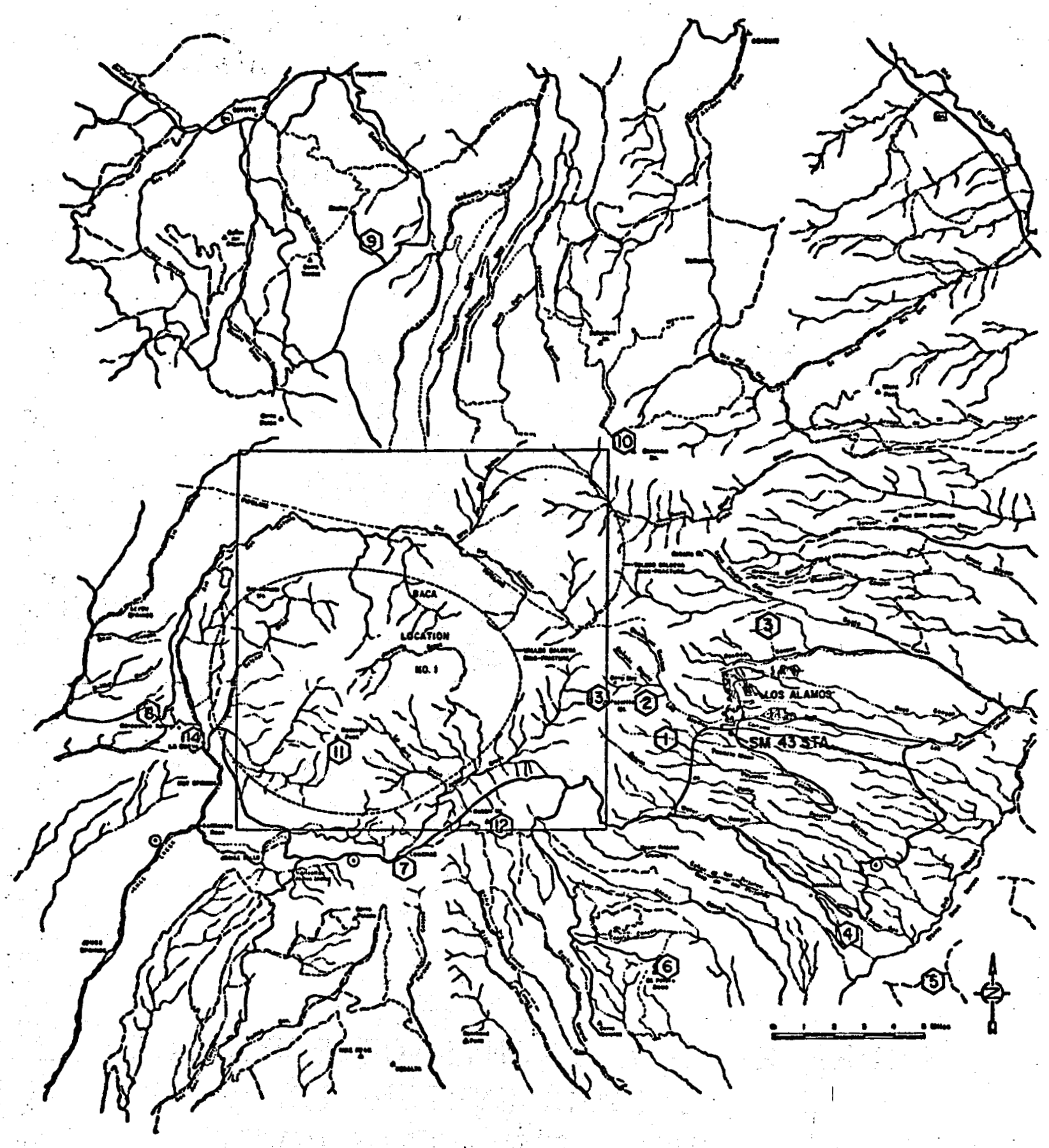

Figure 1. Tentative Site for Seismic and/or Radio Telemetry Relays 
TIME CODE GENERATOR

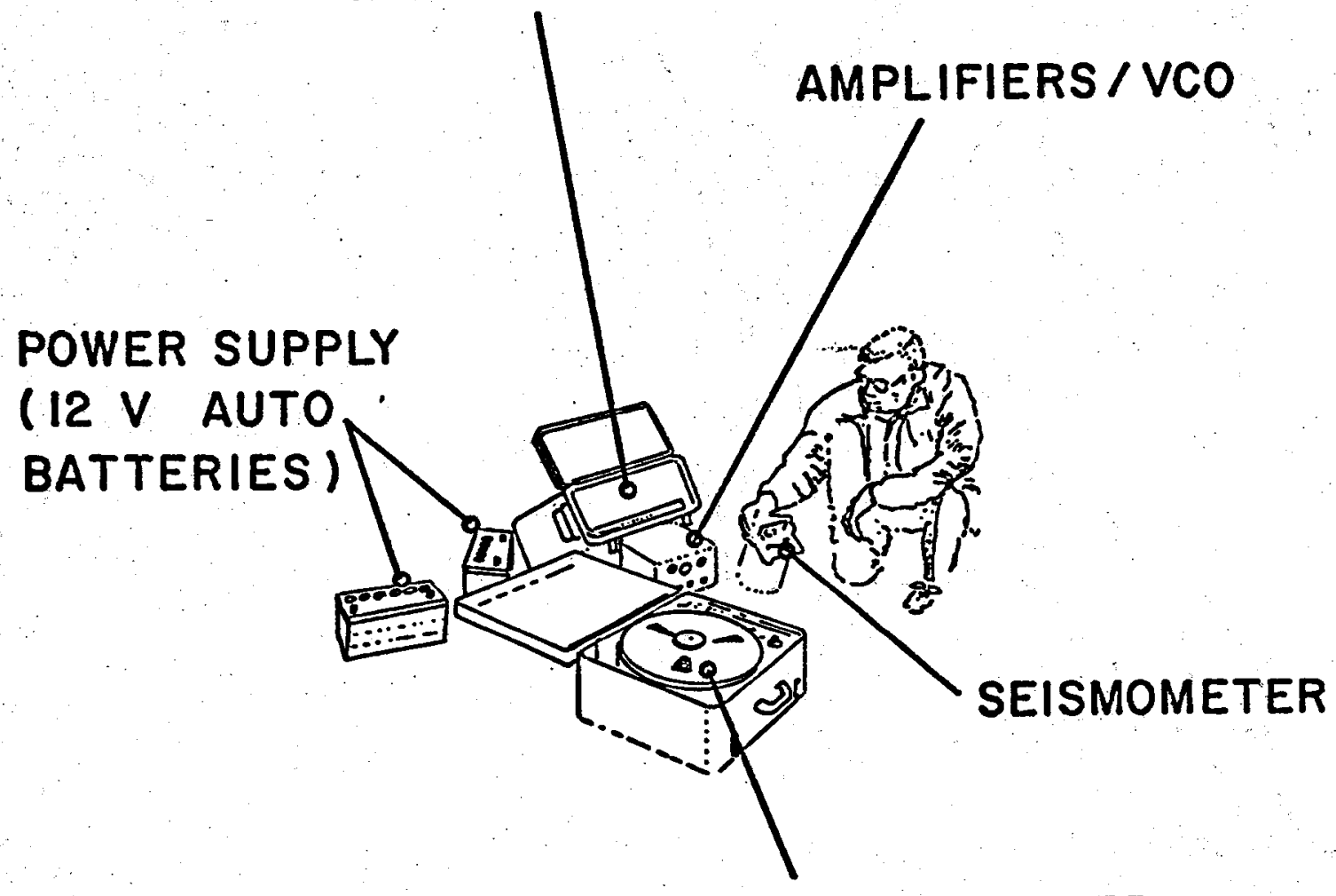

PORTABLE TAPE RECORDER

FIGURE 2. COMPONENTS OF PORTABLE

SEISMIC SYSTEM TO BE

USED FOR SITE SURVEY.

CM:344(120) 